\title{
$\beta$ cells keep bad epigenetic memories of palmitate
}

\author{
Delphine Fradin ${ }^{1}$ and Pierre Bougnères ${ }^{1,2^{*}}$
}

\begin{abstract}
Palmitic acid, or hexadecanoic acid, a 16-carbon saturated fatty acid (FA), accounts for approximately 38\% of the total circulating FA in lean or obese humans. In an article published in BMC Medicine, Hall et al. report that cultured islets from healthy donors, when exposed to palmitate, undergo changes in CpG methylation that are associated with modifications of expression in 290 genes. Their results provide a first look at the mechanisms used by the endocrine pancreas of humans to keep a durable genomic imprint from their exposure to FA that can influence gene expression and possibly cell phenotype in the long term. It is likely that such studies will help understand the epigenetic response of $\beta$ cells to a disturbed metabolic environment, especially one created by obesity.

Please see related article: http://www.biomedcentral.com/1741-7015/12/103
\end{abstract}

Keywords: pancreatic cells, fatty acids, palmitate, epigenetics, gene expression, type 2 diabetes, islets of Langerhans, obesity, DNA methylation

\section{Background}

In order to understand the findings of Hall et al. [1] one would have to ask why would $\beta$ cells keep an epigenetic memory of prior exposure to fatty acids (FA)? The $\beta$ cells continuously receive and integrate multiple neurosecretory, endocrine and metabolic signals originating mostly from the brain. Furthermore, they are also equipped to sense the circulating concentration of energy substrates such as glucose or FA produced by the liver and the adipose tissue, respectively. In contrast to glucose, plasma FA varies over a physiological ten-fold concentration range in response to the whole spectrum of 'fight-or-flight; activities that were common in the early times of Homo sapiens during everyday life: strenuous or prolonged physical activity [2], protracted fasting, fear, psychological stress [3], cold exposure [4] and exercise in cold temperatures [5]. In each of these situations, an almost immediate increase in circulating FA up to approximately $2 \mathrm{mmol} / \mathrm{L}$ is caused by $\beta$-adrenergic stimulation of adipose tissue lipolysis. Lasting more than several hours, the increase in FA is intended to provide readily oxidizable fuels to skeletal

\footnotetext{
* Correspondence: pierre.bougneres@inserm.fr

${ }^{1}$ Inserm U986, Pincus Building, Bicêtre Hospital, Paris Sud University, 94275 Le Kremlin Bicêtre, France

${ }^{2}$ AP-HP, Department of Pediatric Endocrinology, Bicêtre Hospital, Pôle I3E,

Paris Sud University, rue du Général Leclerc, 94275 Le Kremlin Bicêtre, France
}

muscle and heart and spare glucose for concomitant brain activity. Insulin secretion, a major player in this metabolic response, decreases in response to the secreted catecholamines. This decrease contrasts with the increased insulin secretion elicited by FA when they are infused alone, a situation where $\beta$ cell activity is not shut down by catecholamines [6]. Palmitate is also increased in other circumstances of normal human physiology. The palmitate level increases during pregnancy [7] (but does not flow from mother to fetus) and during lactation. Birth is associated with massive palmitate release [8]. The human $\beta$ cells are thus accustomed to facing transient increases in palmitate concentrations at times as part of normal life. It would be tempting to speculate that since these events are more than common, $\beta$ cells would find little interest in keeping memories of such short-lived elevations of FA.

\section{Fatty acids from obesity to type $\mathbf{2}$ diabetes}

What early human $\beta$ cells are not used to facing is a protracted elevation of plasma FA that lasts for years and is not associated with catecholamine secretion. This is precisely the abnormal situation seen today in millions of humans accumulating fat and becoming obese, in whom mounting insulin resistance of the adipose tissue begets FA release from fat stores. While this is occurring, $\beta$ cells synthesize and secrete abundant insulin,

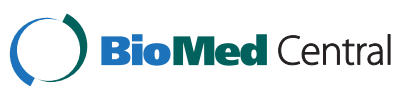


proliferate and enlarge [9]. Many factors have potential roles in the regulation of obesity-driven $\beta$-cell proliferation, including nutrients, insulin, incretins, hepatocyte growth factor, and recently identified liver-derived secreted factors. Much is still unknown about the proliferative pathways involved and the regulation of $\beta$-cell replication. Nonetheless, as the duration and/or the severity of obesity persist, beta cell mass decays and fails to compensate for insulin resistance. This, together with $\beta$-cell dysfunction, leads to the onset of type 2 diabetes (T2D). It is becoming evident that elements in insulin signal-transduction pathways are key to regulating $\beta$ cell growth. Increased $\beta$ cell apoptosis is an important factor contributing to $\beta$ cell loss and the onset of T2D [10].

What is the basis of $\beta$ cell failure in T2D? FA have long been shown to play a deleterious role, not only in peripheral tissues [11], but also in the endocrine pancreas by affecting the tenuous balance between effective pancreatic $\beta$-cell mass (through FA-induced lipotoxicity) and insulin resistance (which increases circulating FA) $[12,13]$. In contrast with the transient FA elevations occurring in normal life, when $\beta$ cells cease their secretory activity, the sustained FA elevations of obese patients [14] or of non-obese patients with T2D [15] become part of the abnormal metabolic environment of $\beta$ cells that are chronically overstimulated by both insulin resistance and hyperglycemia. At the $\beta$ cell level this exposure to high FA levels and high insulin secretory activity by the pancreas represents a mismatch versus the evolutionary 'natural' situation.

\section{The epigenetics of lipotoxicity to the endocrine pancreas}

To unravel the epigenetic effects of FA on $\beta$ cells, Hall et al. [1] studied changes in DNA methylation at CpG nucleotides induced by $1 \mathrm{mmol} / \mathrm{L}$ palmitate in cultured human pancreatic islets. They found that palmitate slightly but significantly increased the level of DNA methylation (44.9\% versus $43.9 \%$ ) in most regions of the genome, including regions involved in the regulation of gene expression, such as promoters and $\mathrm{CpG}$ island shores or shelves, not $\mathrm{CpG}$ islands themselves. To those who are not familiar with the expression of methylation as a percentage, the finding means that when exposed to palmitate, approximately $1 \%$ more of the cultured $\beta$ cells became methylated at the said genomic regions. Even if statistically significant, this is nonetheless a minor change at the level of the whole $\beta$ cell population. More importantly, exposure to palmitate changed the degree of DNA methylation of 46,977 sites at the level of $P<0.05$, but none reached the significant false discovery rate (FDR) q-value of 0.05 . A total of 4,561 sites, including 2,753 genes, displayed increased DNA methylation due to palmitate treatment while only 129 sites (94 genes) showed decreased DNA methylation. In this case, the changes in the islet cell population appear more biologically important, since $46 \%$ to $84 \%$ of the cells seemed to change their methylation status at specific gene positions due to palmitate treatment. Palmitate treatment of the cultured islets also altered glucoseinduced insulin secretion and modified the expression of 1,860 genes that were down- or up-regulated. By integrating DNA methylation and gene expression data, 290 genes were found to show concomitant changes both in expression and in CpG methylation, most showing a decreased expression and an increase of DNA methylation. In cultured islets from donors affected by T2D, Hall et al. [1] observed that 37 of the previously found 1,860 genes showed changes in expression versus non-diabetic donors. Previous studies have already examined the effect of palmitate on gene expression in human islets $[16,17]$ and it will be interesting to compare the results of the three studies to determine how consistent they are.

\section{Conclusions}

The experimental system used by Hall et al. [1] to study DNA methylation is not ideal. First, islets in culture were $80 \%$ pure and were not composed uniquely of only $\beta$ cells. Thus, some of the observed DNA methylation changes might reflect those occurring in non- $\beta$ cells. Secondly, these islets are isolated from their normal physiological neuro-hormonal and metabolic signals. This may explain why cultured islets secrete less insulin when exposed to FA, while in vivo acute exposure of islets to FA is associated with increased insulin secretion in healthy subjects [6]. Thirdly, challenges exist also for the study of islets from donors with T2D, that tend to be much more sensitive to the isolation procedures compared to islets cultured from non-diabetic controls [17]. In addition, islets from donors with T2D may include cells from the inflammasome, possibly associated with T2D [18]. Nevertheless, the observation of palmitateinduced changes in DNA methylation paves the way for further defining the metabolic memory of $\beta$ cells at an epigenetic level. In this respect, it would have been interesting to know if Hall et al. [1] found differentially methylated regions in islets from T2D donors versus non-diabetic islets, or if they have compared their methylation data with those collected by Dayeh et al. [19] and Volkmar et al. [20] for a combined analysis, one that is made mandatory by the small number of islet donors that can be analyzed by any individual investigator. Indeed, then, it is premature to comment further on the islet-expressed genes whose methylation status is altered by palmitate.

Instead of highlighting imperfections of the cultured islet system or lamenting the limited statistical relevance of a small number of pancreatic samples from heterogeneous groups of patients and controls, one should enjoy the preliminary insights provided by the epigenetic analysis in the 
master organ that drives the pathophysiology of T2D and consider the limitations as opportunities for additional research to clarify further the full extent of the clinical relevance of the tantalizing data provided by Hall et al. [1]. Clearly, this must be done since millions of modern obese humans continuously expose their $\beta$ cells to an abnormal FA environment.

\section{Abbreviations \\ FA: fatty acids; FDR: false discovery rate; T2D: type 2 diabetes.}

\section{Competing interests}

The authors declare they have no competing interests.

\section{Authors' contributions}

Both authors contributed to the conception of the article. PB drafted the article. Both authors were involved in editing and revision of the manuscript and both authors read and approved the final manuscript.

\section{Acknowledgements}

DF is employed by INSERM. PB is employed by the University of Paris Sud and Groupe Hospitalier Paris Sud, Hôpital Bicêtre. The authors acknowledge Dennis Bier for editorial help. There was no funding to directly support the writing of this manuscript.

Received: 12 June 2014 Accepted: 12 June 2014

Published: 23 Jun 2014

\section{References}

1. Hall E, Volkov P, Dayeh T, Bacos K, Ronn T, Dekker Nitert M, Ling C: Effect of palmitate on genome-wide mRNA expression and DNA methylation patterns in human pancreatic islet. BMC Medicine 2014, 12:103.

2. Ahlborg G, Felig P, Hagenfeldt L, Hendler R, Wahren J: Substrate turnover during prolonged exercise in man. Splanchnic and leg metabolism of glucose, free fatty acids, and amino acids. J Clin Invest 1974, 53:1080-1090.

3. Patterson SM, Matthews KA, Allen MT, Owens JF: Stress-induced hemoconcentration of blood cells and lipids in healthy women during acute psychological stress. Health Psychol 1995, 14:319-324.

4. Glennon JA, Brech WJ, Gordon ES: Evaluation of an epinephrine test in obesity. Metabolism 1965, 14:1240-1242.

5. Layden JD, Malkova D, Nimmo MA: During exercise in the cold increased availability of plasma nonesterified fatty acids does not affect the pattern of substrate oxidation. Metabolism 2004, 53:203-208.

6. Michaliszyn SF, Bonadonna RC, Sjaarda LA, Lee S, Farchoukh L, Arslanian SA: Beta-cell lipotoxicity in response to free fatty acid elevation in prepubertal youth: African American versus Caucasian contrast. Diabetes 2013, 62:2917-2922.

7. Homko CJ, Sivan E, Reece EA, Boden G: Fuel metabolism during pregnancy. Semin Reprod Endocrinol 1999, 17:119-125.

8. Bougneres PF, Karl IE, Hillman LS, Bier DM: Lipid transport in the human newborn. Palmitate and glycerol turnover and the contribution of glycerol to neonatal hepatic glucose output. J Clin Invest 1982, 70:262-270.

9. Linnemann AK, Baan M, Davis DB: Pancreatic beta-cell proliferation in obesity. Adv Nutr 2014, 5:278-288.

10. Rhodes CJ: Type 2 diabetes-a matter of beta-cell life and death? Science 2005, 307:380-384.

11. McGarry JD: What if Minkowski had been ageusic? An alternative angle on diabetes. Science 1992, 258:766-770.

12. Boden G: Role of fatty acids in the pathogenesis of insulin resistance and NIDDM. Diabetes 1997, 46:3-10.

13. Poitout V, Robertson RP: Glucolipotoxicity: fuel excess and beta-cell dysfunction. Endocr Rev 2008, 29:351-366.

14. Gordon ES: Efficiency of energy metabolism in obesity. Am J Clin Nutr 1968, 21:1480-1485.

15. Reaven GM, Hollenbeck C, Jeng CY, Wu MS, Chen YD: Measurement of plasma glucose, free fatty acid, lactate, and insulin for $24 \mathrm{~h}$ in patients with NIDDM. Diabetes 1988, 37:1020-1024.

16. Choi HJ, Hwang S, Lee SH, Lee YR, Shin J, Park KS, Cho YM: Genome-wide identification of palmitate-regulated immediate early genes and target genes in pancreatic beta-cells reveals a central role of NF-kappaB. Mol Biol Rep 2012, 39:6781-6789.

17. Kirkpatrick CL, Marchetti P, Purrello F, Piro S, Bugliani M, Bosco D, de Koning EJ, Engelse MA, Kerr-Conte J, Pattou F, Wollheim CB: Type 2 diabetes susceptibility gene expression in normal or diabetic sorted human alpha and beta cells: correlations with age or BMI of islet donors. PLoS One 2010, 5:e11053.

18. Schroder K, Zhou R, Tschopp J: The NLRP3 inflammasome: a sensor for metabolic danger? Science 2010, 327:296-300.

19. Dayeh T, Volkov P, Salo S, Hall E, Nilsson E, Olsson AH, Kirkpatrick CL, Wollheim CB, Eliasson L, Ronn T, Bacos K, Ling C: Genome-wide DNA methylation analysis of human pancreatic islets from type 2 diabetic and non-diabetic donors identifies candidate genes that influence insulin secretion. PLOS Genet 2014, 10:e1004160.

20. Volkmar M, Dedeurwaerder S, Cunha DA, Ndlovu MN, Defrance M, Deplus R, Calonne E, Volkmar U, Igoillo-Esteve M, Naamane N, Del Guerra S, Masini M, Bugliani M, Marchetti P, Cnop M, Eizirik DL, Fuks F: DNA methylation profiling identifies epigenetic dysregulation in pancreatic islets from type 2 diabetic patients. EMBO J 2012, 31:1405-1426.

10.1186/1741-7015-12-104

Cite this article as: Fradin and Bougnères: $\beta$ cells keep bad epigenetic memories of palmitate. BMC Medicine 2014, 12:104

\section{Submit your next manuscript to BioMed Central and take full advantage of:}

- Convenient online submission

- Thorough peer review

- No space constraints or color figure charges

- Immediate publication on acceptance

- Inclusion in PubMed, CAS, Scopus and Google Scholar

- Research which is freely available for redistribution 